\title{
FAKTOR-FAKTOR KUALITAS PELAYANAN DALAM \\ MEWUJUDKAN KEPUASAN MAHASISWA \\ (Studi Kasus Pada Mahasiswa Di Fakultas Ekonomi Uniku)
}

\author{
Dadang Suhardi, S.E, M.M \\ Ilham Akbar, SE., M.Si \\ ilhamakbar@uniku.ac.id
}

\begin{abstract}
ABSTRAK
Penelitian ini bertujuan untuk mengetahui tingkat kepuasan mahasiswa Fakultas Ekonomi Uniku dan untuk menganalisis (1) pengaruh tangibles terhadap kepuasan mahasiswa, (2) pengaruh reliabilty terhadap kepuasan mahasiswa, (3) pengaruh responssive terhadapa kepuasan mahasiswa, (4) pengaruh assurance terhadap kepuasan mahasiswa dan (5) pengaruh emphaty terhadap kepuasan mahasiswa sebagai faktorfaktor yang mempengaruhinya. Penelitian ini bersifat eksploratif dengan subjek mahasiswa program studi manajemen dan akuntansi Fakultas Ekonomi Uniku. Teknik pengumpulan data menggunakan angket/kuesioner dan menggunakan metode kuantitatif deskriktif. Berdasarkan hasil Uji hipotesis (1) Tangibles menunjukkan bahwa terdapat nilai thitung sebesar 3.370>0.299 dan signifikansi sebesar 0,001 $(0,001<0,05)$ Tangible berpengaruh signifikan terhadap kepuasan mahasiswa (2) reliability menunjukkan bahwa terdapat nilai thitung sebesar $1.400>0.166$ dan nilai signifikansi sebesar 0,165 $(0,165>0,05)$ artinya Reliability tidak berpengaruh terhadap kepuasan mahasiswa (3) responssive menunjukkan bahwa terdapat nilai thitung sebesar $1.526>0.145$ dan nilai signifikansi sebesar $0,130(0,130>0,05)$ artinya Responsiveness tidak berpengaruh terhadap kepuasan mahasiswa(4) assurance menunjukkan bahwa terdapat nilai thitung sebesar $2.251>$ 0,236 dan nilai signifikansi sebesar 0,027 $(0,027<0,05)$ artinya Assurance berpengaruh signifikan terhadap kepuasan mahasiswa (5) emphaty menunjukkan bahwa terdapat nilai thitung sebesar $1.110>0.095$ dan nilai signifikansi sebesar $0,270(0,270>0,05)$ artinya empathy berpengaruh terhadap kepuasan mahasiswa
\end{abstract}

Kata kunci :tangibles, reliabilty,assurance,responssive,emphaty

\section{KATA PENGANTAR}

Tingkat kepuasan seseorang terhadap sebuah produk atau jasa selalu berubah-ubah dari waktu ke waktu. Pada dasarnya kepuasan dan ketidakpuasan seorang konsumen atau pelanggan atas suatu produk atau jasa akan berpengaruh dan berdampak pada pola perilaku seorang 
konsumen atau pelanggan selanjutnya. Hal ini dapat dibuktikan dengan mengamati tindakan seorang konsumen atau pelanggan setelah terjadinya proses pembelian suatu barang(Philip Kotler, 2005:113).

Apabila pelanggan atau konsumen merasa puas atas produk atau jasa yang mereka dapatkan, maka dia akan menunjukkan atau melakukan suatu tindakan yang cenderung melakukan pembelian kembali produk yang sama. Pelanggan yang puas juga akan cenderung memberikan referensi dan menceritakan hal yang baik mengenai produk yang mereka beli kepada orang lain. Hal ini bertentangan dengan pelanggan yang yang merasa tidak puas. Pelanggan yang merasa tidak puas akan lebih memilih untuk mencari informasi pihak penyedia produk atau jasa lain yang sejenis yang dibutuhkannya dan menggunakan produk yang sejenis dengan merek yang berbeda, serta pelanggan tersebut tidak akan merekomendasikan dan memberikan referensi mengenai produk atau jasa tersebut. Proses itu akan terus berulang sampai konsumen merasa terpuaskan atas keputusan pembelian suatu produknya.

Masalah pendidikan merupakan masalah bersama yang harus diselesaikan oleh seluruh komponen bangsa. Pendidikan di suatu bangsa harus dilaksanakan dengan baik yang berguna untuk meningkatkan kualitas sumber daya manusia. Dalam upaya peningkatan kualitas sumber daya manusia maka diperlukan peningkatan strata pendidikan tinggi pada level sarjana maupun pascasarjana. Setiap lembaga pendidikan mempunyai perencanaan operasional yang disusun dan direvisi secara berkala. Perencanaan operasional yang disusun tersebut berfungsi sebagai strategi suatu lembaga pendidikan untuk mencapai visi maupun misi suatu lembaga pendidikan yang bersangkutan. Strategi tersebut mencakup mengenai hal-hal yang ingin dicapai dalam jangka serta ringkasan perencanaan dan pengembangan sumber-sumber daya yang dimiliki seperti sumber daya modal dan sumber daya manusia (Rochaety dkk, 2005: 21). Permasalahan ini memungkinkan adanya berbagai hal yang dapat mempengaruhi kepuasan konsumen. Apabila tidak segera diatasi oleh pimpinan Fakultas Ekonomi Uniku dalam kaitannya dengan pelayanan akan menimbulkan ketidak puasan konsumen. Oleh karena itu, pimpinan Fakultas Ekonomi Uniku harus mengatasi permasalah tersebut dengan mengambil langkah tepat untuk memperhatikan faktor kualitas pelayanan.

Kurangnya kepuasan yang dicapai oleh mahasiswa Fakultas Ekonomi Uniku memunculkan berbagai macam keluhan, seperti: masih terdapatnya tenaga kependidikan yang kurang tanggap terhadap konsumen. Pimpinan Fakultas Ekonomi Uniku memahami kebutuhan dan keinginan mahasiswa sehingga dalam usaha memenuhi kebutuhan dan keinginan mahasiswa tersebut pimpinan Fakultas Ekonomi Uniku dapat memberikan pelayanan yang tepat untuk memberikan kepuasan kepada mahasiswa.

Kualitas pelayanan memiliki hubungan yang erat dengan kepuasan konsumen. Kualitas pelayanan merupakan upaya pemenuhan kebutuhan 
dan keinginan pelanggan atau konsumen dimana kualitas pelayanan ini memerlukan ketepatan penyampaian pelayanan dalam mengimbangi atau memenuhi apa yang menjadi harapan dari seorang pelanggan atau konsumen (Tjiptono, 2007:32). Penelitian yang telah dilakukan Fariza (2008) dimana Fariza (2008) ini melakukan penelitian tentang analisis faktor-faktor yang mempengaruhi kepuasan pelanggan GSM Indosat di kota Semarang menjelaskan bahwa harga memiliki pengaruh yang positif terhadap kepuasan pelanggan. Dalam upaya peningkatan pelayanan di bidang pendidikan maka terdapat beberapa dimensi kualitas layanan yang dibutuhkan yaitu berupa bukti fisik atau tangible, keterandalan atau reliability, daya tanggap atau responsiveness, jaminan atau assurance dan empati atau empathy.

Dari beberapa hasil penelitian tersebut terdapat kaitan dengan penelitian yang akan dilakukan peneliti. Akan tetapi secara khusus, tidak satupun dari hasil penelitian tersebut yang sama persis dengan penelitian yang dilakukan oleh peneliti. Sehingga peneliti perlu melakukan penelitian "Faktor-Faktor Kualitas Pelayanan Dalam Mewujudkan Kepuasan Mahasiswa (Studi Kasus Pada Mahasiswa di Fakultas Ekonomi Uniku".

\section{TINJAUAN LITERATUR}

\section{Pengertian pemasaran}

Kotler (2009:112) mengemukakan bahwa pemasaran adalah proses sosial yang didalamnya berisikan individu dan kelompok sehingga individu dan kelompok ini dapat memperoleh $\mathrm{m}$ apa yang mereka butuhkan dan inginkan dengan cara menciptakan atau membuat, menawarkan dan secara bebas mepertukarkan produk yang dianggap bernilai dengan orang lain atau pihak lain.

\section{Pengertian manajemen pemasaran}

Kotler (2009:114) mengemukakan bahwa manajemen pemasaran adalah seni dan ilmu memilih pasar sasaran dan mendapatkan, menjaga serta menumbukan pelanggan dengan menciptakan, menyerahkan dan mengkomunikasikan nilai pelanggan yang unggul.

\section{Kualitas pelayanan}

Tjiptono (2007:28) mengemukakan bahwa kualitas pelayanan adalah upaya penyampaian jasa yang diberikan guna memenuhi kebutuhan dan keinginan pelanggan atau konsumen serta kualitas pelayanan ini memerlukan ketepatan penyampaian jasa kepada pelanggan atau konsumen yang berguna untuk mengimbangi apa yang menjadi harapan konsumen atau pelanggan. Menurut Rangkuti (2006:64) definisi kualitas pelayanan adalah penyampaian jasa yang akan melebihi tingkat kepentingan pelanggan. Adapun faktor yang dapat mempengaruhi kualitas pelayanan merupakan jasa yang sesuai dengan harapan pelanggan atau konsumen atau jasa yang diharapkan oleh pelanggan atau konsumen. Apabila seorang pemberi jasa memberikan jasa yang 
diharapkan pada seorang konsumen maka kualitas pelayanan tersebut akan dipersepsikan baik atau positif. Apalagi kalau jasa yang dipersepsikan tersebut melebihi jasa yang diharapkan, maka kualitas jasa yang dipersepsikan sebagai kualitas ideal.

\section{- Dimensi Kualitas Pelayanan}

Parasuraman, Zeithaml dan Berry (1985) dalam Tjiptono (2005:72) mengemukakan terdapat 5 dimensi yang dapat mengukur kualitas pelayanan atau service quality yaitu :

1. Tangibles (bukti langsung) merupakan bukti nyata dari perhatian dan kepedulian yang diberikan oleh penyedia jasa atau pemberi jasa kepada pelanggan atau konsumen. Dimensi Tangibels ini dianggap penting dimana dimensi ini dapat menumbuhkan dan membangun image penyedia jasa hal ini sangat berpengaruh terutama bagi pelanggan atau konsumen baru memakai layanan penyedia jasa tersebut yang digunakan untuk mengevaluasi dan mereview kualitas jasa yang diberikan oleh penyedia jasa. Menurut Zeithaml. et al. 1985 (Aviliani dan Wilfridus, 2011:10) wujud fisik (tangible) adalah kebutuhan pelanggan atau konsumen yang berfokus terhadap fasilitas fisik yang dimiliki oleh penyedia jasa seperti kebersihan gedung atau ruangan, ruangan atau gedung, kerapian dan kenyamanan ruangan atau gedung, kelengkapan peralatan yang disediakan oleh penyedia jasa, tersedia tempat parkir, sarana komunikasi, serta penampilan karyawan

2. Reliability (keandalan) merupakan kemampuan perusahaan dalam melaksanakan jasanya sesuai dengan apa yang telah dijanjikan atau apa yang telah ditentukan untuk konsumen atau pelanggan dan djasa ini disampaikan secara tepat waktu. Dimensi ini dianggap penting karena apabila jasa yang diberikan oleh penyedia jasa tidak sesuai dengan yang dijanjikan atau yang ditentukan oleh peneydia jasa maka kepuasan yang dirasakan oleh konsumen atau pelanggan akan menurun. Atribut - atribut yang berada dalam dimensi reliability ini antara lain adalah memberikan pelayanan sesuai janji dan apa yang telah ditentukan oleh penyedia jasa, memberikan pelayanan yang baik dan berkualitas saat kesan pertama kepada konsumen atau pelanggan, memiliki rasa tanggung jawab dengan penanganan konsumen akan masalah pelayanan, dan tidak membedakan satu konsumen atau pleanggan satu dengan yang lainnya, memberikan pelayanan kepada konsumen atau pelanggan tepat waktu, memberikan informasi kepada pelanggan atau konsumen mengenai waktu pelayanan yang dijanjikan atau yang telah ditentukan akan direalisasikan.

3. Responsiveness (ketanggapan) merupakan kemampuan perusahaan dalam merespon konsumen atau pelanggan secara tanggap dan cepat. Hal ini dapat yang dilakukan secara langsung oleh karyawan perusahaan tersebut dimana karyawan perusahaan dapat 
memberikan pelayanan kepada setiap pelanggan atau konsumen dengan cepat, sigap, dan tanggap. Daya tanggap yang cepat yang dilakukan oleh penyedia jasa termasuk karyawan penyedia jasa dapat menumbuhkan dan mengembangkan serta meningkatkan anggapan dan persepsi yang baik dan positif terhadap kualitas jasa yang diberikan oleh penyedia jasa. Dimensi ini berfokus pada penekanan terhadap kecepatan karyawan dan perhatian dimana karyawan ini bertugas untuk menanggapi dan merespon permintaan, pertanyaan, dan keluhan konsumen. Atribut-atribut yang ada dalam dimensi ini adalah memberikan palayanan yang tanggap, sigap, dan cepat, merelaan untuk membantu atau menolong konsumen, siap, bersedia, dan tanggap untuk menangani respon permintaan dari para konsumen.

4. Assurance (jaminan) merupakan pengetahuan dan perilaku yang dimiliki oleh karyawan atau pekerja penyedia jasa yang berfungsi untuk membangun dan menumbuhkan sebuah kepercayaan dan keyakinan pada diri konsumen atau pelanggan sehingga pelanggan tersebut memilih menggunakan dan mengkonsumsi jasa yang ditawarkan dibandingkan jasa atau produk lainnya. Dimensi ini dianggap sangat penting karena dimensi ini melibatkan anggapan dan persepsi seorang pelanggan atau konsumen terhadap risiko ketidakpastian yang tinggi yang terhadap kemampuan penyedia jasa dalam bisa tidaknya menyediakan jasa sesuai dengan yang diharapkan oleh konsumen atau pelanggan. Atribut-atribut yang ada di dalam dimensi assurance ini adalah karyawan dapat memberikan jaminan berupa kepercayaan diri dan keyakinan diri kepada konsumen, karyawan dapat membuat konsumen merasa aman dan nyaman saat menggunakan jasa pelayanan perusahaan, karyawan memiiki rasa sopan, karyawan yang memiliki pengetahuan dan wawasan yang luas sehingga dapat menjawab pertanyaan dari konsumen

5. Emphaty (Empati) merupakan kemampuan perusahaan dalam memberikan perhatian kepada pelanggan atau konsumen. Emphaty ini dapat dilakukan oleh karyawan atau pekerja pada perusahaan tersebut dengan memberikan perhatian kepada konsumen secara individu, hal ini termasuk juga kepekaanakan seorang karyawan atas kebutuhan dan keinginan pelanggan atau konsumen.

\section{- Kepuasan Konsumen}

Kotler (2002:42) mengemukakan bahwa kepuasan adalah perasaan seseorang yang muncul setelah melakukan suatu perbandingan antara kesan atau persepsi atau anggapan seseorang tersebut terhadap kinerja atau hasil dari suatu produk dan harapan-harapan yang ingin diperoleh oleh orang tersebut. Dalam menciptakan kepuasan pelanggan, maka perusahaan harus dapat menciptakan, membuat, mengolah, dan mengelola suatu sistem yang berkualitas yang digunakan untuk 
memperoleh pelanggan atau konsumen yang lebih banyak dan perusahaan harus memiliki kemampuan untuk mempertahankan pelanggan atau konsumennya.

\section{METODE,DATA DAN ANALISIS}

Kotler (2007:185) mengemukakan 4 metode untuk mengukur kepuasan pelanggan, yaitu :

1. Sistem keluhan dan saran, sebuah perusahaan yang berfokus pada pelanggan harus dapat mempermudah pelanggannya untuk memberikan saran, pendapat dan keluhan mereka.

2. Survei kepuasan konsumen, pengukuran kepuasan konsumen melalui metode ini, dapat di lakukan dengan berbagai cara diantarannya :

a. Directly Reported Statisfaction yaitu suatu pengukuran dilakukan atau dilaksanakan secara langsung melalui pertanyaan.

b. Derived Dissatifactoin yaitu pengukuran kepuasan konsumen melalui pertanyaan mengenai besarnya harapan pelanggann atau konsumen terhadap atribut tertentu dan besarnya kinerja yang telah mereka rasakan.

c. Problem Analysis merupakan pengukuran kepuasan konsumen dengan cara konsumen yang dijadikan responden diminta untuk mengungkapkan masalah-masalah dengan mereka hadapi berkaitan dengan penawaran dari manajemen perusahaan dan saran-saran untuk melakukan perbaikan

d. Importance - Performance Analysis adalah pengukuran kepuasan konsumen melalui cara responden diminta meranking berbagai elemen dari penawaran beradasrkan derajat pentingnya setiap elemen tersebut dan kinerja perusahaan dalam masing - masing elemen.

3. Belanja siluman ( Ghost Shopping) adalah metode yang dilakukan untuk mengukur kepuasan konsumen dengan cara meperkerjakan beberapa orang (Ghost shopper) untuk berperan atau bersikap sebagai konsumen potensial produk perusahaan dan menyampaikan kekuatan dan kelemahan produk perusahan pesaing berdasarkan pengalaman mereka.

4. Analisis pelanggan yang hilang (lost customer analysis), pihak perusahaan berusaha menghubungi para konsumem yang sudah berhenti menjadi pelanggan atau beralih ke perusahaan lain

\section{- Indikator Kepuasan Pelanggan}

Philip Kotler (2008:174-177) mengemukakan bahwa indikator dari kepuasan konsumen terdiri dari :

1. Adanya rasa senang.

2. Melakukan pemeriksaan pembelian ulang.

3. Terpenuhinya harapan.

4. Merekomendasikan kepada orang lain. 


\section{- Kerangka Berpikir}

Kualitas pelayanan adalah suatu karakteristik, ciri atau sifat suatu produk atau pelayanan yang berpengaruh pada kemampuan untuk memuaskan kebutuhan konsumen. Kepuasan adalah tanggapan konsumen dan penilaian konsumen atas terpenuhi kebutuhannya. Terciptanya kepuasan pelanggan akan memberikan manfaat kepada perusahaan, beberapa diantara manfaat tersebut adalah dapat membuat hubungan antara perusahaan dan pelanggan atau konsumen menjadi harmonis dan baik, kepuasan pelanggan atau konsumen menjadi dasar bagi pelanggan untuk melakukan pembelian ulang atas produk atau jasa yang ditawarkan oleh perusahaan dan dapat menciptakan loyalitas seorang pelanggan (Tjiptono, 2004:28).

Intitusi / fakultas harus memahami kebutuhan dan keinginan mahasiswa, sehingga dalam usaha memenuhi kebutuhan dan keinginan mahasiswa tersebut institusi / fakultas dapat menyediakan pelayanan serta strategi pemasaran yang tepat untuk memberikan kepuasan kepada mahasiswa, Bersumber dari tinjauan pustaka, penelitian terdahulu dan tujuan penelitian maka kerangka pemikiran yang menunjukkan keadaan di mana faktor-faktor yang mempengaruhi kepuasan mahasiswa menggunakan layanan jasa dapat dilihat pada bagan berikut :

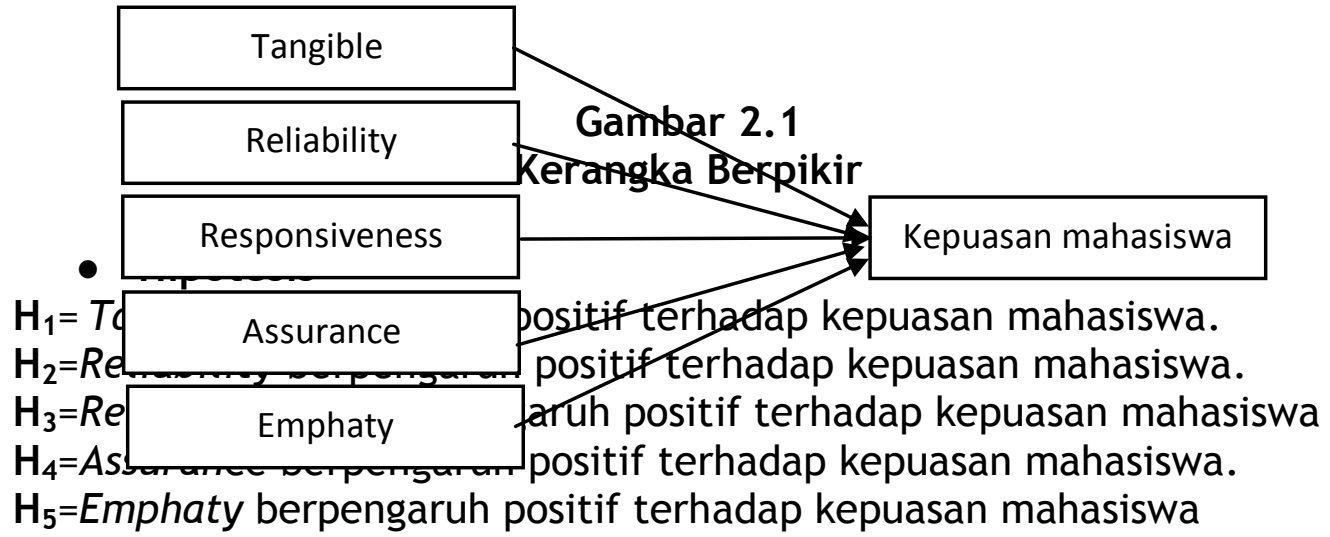

Analisis data yang digunakan dalam penelitian ini adalah analisis deskriptif dan analisis statistik yaitu penelitiannya bertujuan untuk memberikan gambaran mengenai fakta-fakta, sifat serta pengaruh terhadap masing-masing variabel yang diteliti.

- Operasionalisasi variabel

1. Tangible $\left(\mathrm{X}_{1}\right)$

Indikator : bangunan dan interior yang bagus dan menarik, kebersihan dan kenyamanan, kelengkapan fasilitas yang ditawarkan. kebersihan dan kerapian karyawan.

Skala : Interval

2. Reliability $\left(\mathrm{X}_{2}\right)$ 
Indikator : kecepatan dalam melayani mahasiswa, pelayanan yang memuaskan.

Skala : Interval

3. Responsiveness $\left(\mathrm{X}_{3}\right)$

Indikator : tanggap terhadap keluhan pelanggan, kesediaan karyawan Skala membantu pelanggan, kecepatan dalam menyelesaikan masalah.

4. Assurance $\left(\mathrm{X}_{4}\right)$

Indikator : keramahan dalam melayani pelanggan, pengetahuan yang luas, keamanan pelanggan.

Skala : Interval

5. Emphaty $\left(\mathrm{X}_{5}\right)$

Indikator : Mengetahui keinginan pelanggan, mampu berkomunikasi dengan baik.

Skala : Interval

6. Kepuasan Konsumen (Y)

Indikator : kenyamanan yang dirasakan pelanggan pada saat pelayanan diberikan, keyakinan pelanggan atas pelayanan yang diberikan, minat untuk selalu menggunakan jasa, perasaan puas atas perhatian dan pelayanan yang diberikan oleh karyawan.

Skala : Interval

- Populasi dan sampel

Dalam penelitian ini populasinya sebanyak 2.000 mahasiswa antara lain Jumlah mahasiswa aktif program studi manajemen sebanyak 1.263 mahasiswa. sedangkan jumlah mahasiswa aktif ptogram studi akuntansi sebanyak 731 mahasiswa. Kkuran sampel mahasiswa Fakultas Ekonomi UNIKUdengan level of error sebesar 0,1 (10\%) dapat dihitung sebagai berikut:

$$
\begin{gathered}
n=\frac{N}{1+N(e)^{2}}=\frac{2.000}{1+2.000(0,1)^{2}}=\frac{2.000}{21} \\
n=95,238 \text { dibulatkan menjadi } 95
\end{gathered}
$$

Tabel 3.1

Distribusi Sampel

\begin{tabular}{|c|c|c|c|c|}
\hline No & DAERAH & Populasi & \multicolumn{1}{|c|}{ Proporsi } & Sampel \\
\hline 1 & Prodi Manajemen & 1.263 & $1.263 / 2.000 \times 95=59,99$ & 60 \\
\hline 2 & Prodi Akuntansi & 731 & $731 / 2.000 \times 95=34,72$ & 35 \\
\hline & Jumlah & 2.000 & & 95 \\
\hline
\end{tabular}

Sumber : data diolah 2018

- Teknik analisis

Teknik pengumpulan data yang digunakan dalam penelitian ini menggunakan kuesioner (angket) Data yang diperoleh adalah data interval . 
1. Uji instrumen

a. Uji validitas

Dengan jumlah sampel (n) dan tingkat signifikansi 0,05 maka $r$ tabel pada penelitian ini adalah: $r(\alpha ; d f)$. Bila: $r$ hitung $>r$ tabel, berarti pernyataan tersebut dinyatakan valid. $r$ hitung $<r$ tabel, berarti pernyataan tersebut dinyatakan tidak valid.

b. Uji reliabilitas

Uji reabilitas yang di digunakan dalam penelitian dengan bantuan program SPSS sehingga untuk menentukan reliabilitas dapat dilihat dari nilai Cronbach Alpha. Jadi suatu variabel dikatakan reliabel jika memberikan nilai Cronbach Alpha > 0,7 (Nunnally dalam Ghozali, 2013:48).

2. Analisis deskriptif

\begin{tabular}{|c|c|c|c|c|c|c|c|c|c|}
\hline 1 & 2 & 3 & 4 & 5 & 6 & 7 & 8 & 9 & 10 \\
\hline Sangat & \multicolumn{10}{c|}{ tidak }
\end{tabular}

Sangat setuju

Sumber : Sugiyono (2013:140)

Responden yang memberi penilaian dengan angka 10, berarti presepsi responden itu sangat positif, sedangkan bila memberi jawaban pada angka 1, maka presepsi responden sangat negatif. Selanjutnya untuk menetapkan peringkat dalam setiap variabel penelitian dapat dilihat dari perbandingan antar skor aktual dengan skor kriterium (ideal). Skor kriterium (ideal) diperoleh melalui perolehan prediksi nilai tertinggi dikalikan dengan jumlah kuesioner dikalikan jumlah responden sehingga dapat dirumuskan sebagai berikut:

a. Jumlah skor kriterium = skor tertinggi $x$ jumlah butir $x$ jumlah sampel

b. Jumlah skor aktual = jumlah skor angket yang diperoleh

c. Presentase skor yang diperoleh dapat dihitung dengan rumus :

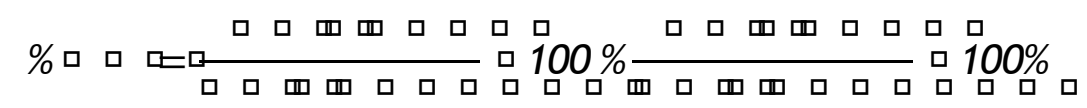

d. Menentukan daerah kriterium menjadi tiga tingkatan dan dapat diperoleh dengan parameter sebagai berikut :

1.) Prosentase ideal yaitu $=100 / 3=33,33 \%$

2.) Nilai $33,33 \%$ ini dijadikan selisih untuk tiap tingkatan sehingga menjadi :

Daerah rendah pada interval $=0 \%-33 \%$

Daerah sedang pada interval $=34 \%-67 \%$

Daerah tinggi pada interval $=68 \%-100 \%$ 


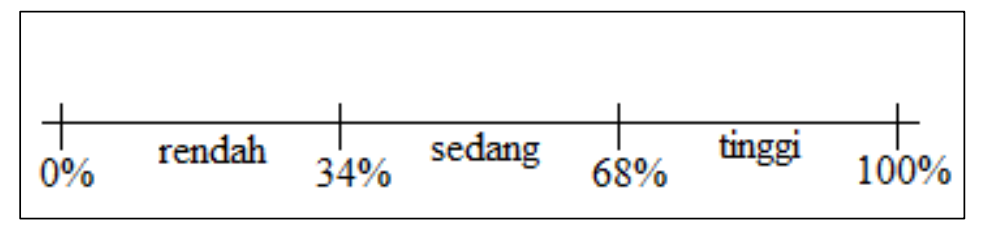

3. Analisis kuantitatif

Gambar 3.1

Daerah Kriterium

Data tersebut harus diklasifikasikan dalam kategori tertentu dengan menggunakan tabel-tabel tertentu untuk memudahkan dalam menganalisis, untuk itu akan digunakan program software SPSS (Statistical Package for Social Science).

4. Uji asumsi klasik

Uji asumsi klasik pada penelitian ini menggunakan uji normalitas, uji multikolinieritas, uji heteroskedastisitas, dan uji autokorelasi.

\section{Uji instrumen dan data penelitian}

\section{- Uji validitas}

Tabel 4.1

Hasil Uji Validitas

\begin{tabular}{|c|c|c|c|c|c|c|c|c|c|}
\hline Variabel & $\begin{array}{c}\text { No } \\
\text { Item }\end{array}$ & $r$ hitung & $r$ tabel & Keterangan & Variabel & $\begin{array}{c}\text { No } \\
\text { Item }\end{array}$ & $r$ hitung & $r$ tabel & Keteran \\
\hline \multirow{7}{*}{ Tangible } & 1 & 0,695 & 0,119 & valid & \multirow{6}{*}{ Assurance } & 1 & 0,642 & 0,119 & $\mathrm{val}$ \\
\hline & 2 & 0,694 & 0,119 & valid & & 2 & 0,753 & 0,119 & \\
\hline & 3 & 0,670 & 0,119 & valid & & 3 & 0,667 & 0,119 & va \\
\hline & 4 & 0,765 & 0,119 & valid & & 4 & 0,560 & 0,119 & \\
\hline & 5 & 0,686 & 0,119 & valid & & 5 & 0,553 & 0,119 & \\
\hline & 6 & 0,505 & 0,119 & valid & & 6 & 0,542 & 0,119 & \\
\hline & 7 & 0,560 & 0,119 & valid & \multirow{6}{*}{ Emphaty } & 1 & 0,595 & 0,119 & \\
\hline \multirow{9}{*}{ Reliability } & 1 & 0,625 & 0,119 & valid & & 2 & 0,618 & 0,119 & \\
\hline & 2 & 0,563 & 0,119 & valid & & 3 & 0,813 & 0,119 & \\
\hline & 3 & 0,562 & 0,119 & valid & & 4 & 0,548 & 0,119 & \\
\hline & 4 & 0,594 & 0,119 & valid & & 5 & 0,569 & 0,119 & \\
\hline & 5 & 0,560 & 0,119 & valid & & 6 & 0,561 & 0,119 & \\
\hline & 6 & 0,558 & 0,119 & valid & \multirow{5}{*}{ Kepuasan } & 1 & 0,685 & 0,119 & \\
\hline & 7 & 0,594 & 0,119 & valid & & 2 & 0,642 & 0,119 & \\
\hline & 8 & 0,743 & 0,119 & valid & & 3 & 0,743 & 0,119 & \\
\hline & 9 & 0,699 & 0,119 & valid & & 4 & 0,821 & 0,119 & \\
\hline \multirow{5}{*}{ Responsiveness } & 1 & 0,682 & 0,119 & valid & & 5 & 0,749 & 0,119 & \\
\hline & 2 & 0,740 & 0,119 & valid & & & & & \\
\hline & 3 & 0,764 & 0,119 & valid & & & & & \\
\hline & 4 & 0,760 & 0,119 & valid & & & & & \\
\hline & 5 & 0,550 & 0,119 & valid & & & & & \\
\hline
\end{tabular}

Sumber :Data primer diolah, 2018

Berdasarkan Tabel tersebut di atas menunjukkan besarnya nilai $r$ hitung seluruh butir pertanyaan nilainya $>r$ table 0,196. Dengan 
demikian dapat disimpulkan bahwa seluruh butir dinyatakan valid dan kuisioner dalam penelitian ini dapat digunakan untuk analisis selanjutnya yaitu regresi linier berganda.

- Uji reliabilitas

Tabel 4.2

Hasil Uji Reliabilitas

\begin{tabular}{|l|c|c|c|}
\hline \multicolumn{1}{|c|}{ variabel } & nilai Alpha Crobach & batas Kritis & keterrangan \\
\hline Tangible & 0,754 & 0,6 & Reliabel \\
\hline Reliability & 0,750 & 0,6 & Reliabel \\
\hline Responsiveness & 0,778 & 0,6 & Reliabel \\
\hline Assurance & 0,746 & 0,6 & Reliabel \\
\hline Emphaty & 0,716 & 0,6 & Reliabel \\
\hline Kepuasan & 0,786 & 0,6 & Reliabel \\
\hline
\end{tabular}

Sumber :Data primer diolah, 2018

Berdasarkan ringkasan hasil uji reliabilitas seperti yang terangkum dalam tabel di atas, dapat diketahui bahwa nilai koefisien Cronbach Alpha seluruh varaibel penelitian lebih besar dari 0,6. Dengan mengacu pada pendapat yang dikemukakan oleh Ghozali (2001), maka semua butir pertanyaan dalam variabel penelitian adalah handal.

\section{Uji asumsi klasik}

- Uji normalitas

Tabel 4.3

Uji Normalitas

\begin{tabular}{|c|c|c|}
\hline Unstandar_residual & Batas & Keterangan \\
\hline 0,961 & 0,05 & Normal \\
\hline
\end{tabular}

Sumber : Data Primer diolah, 2018

Berdasarkan Tabel tersebut di atas dapat diketahui nilai asymp.sig sebesar 0,961 >0,05 sehingga dapat disimpulkan bahwa data berdistribusi normal.

- Uji multikolinieritas

Tabel 4.4

Uji Multikolineartias

\begin{tabular}{|l|c|c|c|}
\hline \multicolumn{1}{|c|}{ Variabel } & Tolerance & VIF & Keterangan \\
\hline Tangible & 0.620 & 1.612 & Tidak terjadi multikolinieritas \\
\hline Reliability & 0.345 & 2.901 & Tidak terjadi multikolinieritas \\
\hline Responsiveness & 0.541 & 1.847 & Tidak terjadi multikolinieritas \\
\hline Assurance & 0.445 & 2.249 & Tidak terjadi multikolinieritas \\
\hline Emphaty & 0.663 & 1.507 & Tidak terjadi multikolinieritas \\
\hline
\end{tabular}

Sumber : Data Primer diolah, 2018

- Uji heteroskedastisitas

Tabel 4.5 
Uji Heteroskedastisitas

\begin{tabular}{|l|c|c|c|}
\hline \multicolumn{1}{|c|}{ Variabel } & sig & batas & Keterangan \\
\hline Tangible & 0.857 & $>0,05$ & Tidak terjadi heterokedasitas \\
\hline Reliability & 0.921 & $>0,05$ & Tidak terjadi heterokedasitas \\
\hline Responsiveness & 0.234 & $>0,05$ & Tidak terjadi heterokedasitas \\
\hline Assurance & 0.845 & $>0,05$ & Tidak terjadi heterokedasitas \\
\hline Emphaty & 0.316 & $>0,05$ & Tidak terjadi heterokedasitas \\
\hline
\end{tabular}

Sumber : Data Primer diolah, 2018

- Uji autokorelasi

\section{Tabel 4.6}

Uji Autokorelasi

\begin{tabular}{|c|c|c|}
\hline Hasil run test & batas & Keterangan \\
\hline 0.050 & 0,05 & Tidak terjadi autokorelasi \\
\hline
\end{tabular}

Sumber : Data Primer diolah, 2018

\section{Analisis hipotesis}

- Analisis regresi linier berganda

Tabel 4.7

Hasil Uji Regresi Linear Berganda

\begin{tabular}{|c|c|c|c|c|c|}
\hline Variabel & $\mathrm{B}$ & beta & $\mathrm{t}$ hitung & Sig t & Keterangan \\
\hline (Constant) & 1.200 & & & & \\
\hline X1 & 0.211 & 0.299 & 3.370 & 0.001 & Signifikan \\
\hline X2 & 0.113 & 0.166 & 1.400 & 0.165 & Tidak Signifikan \\
\hline X3 & 0.120 & 0.145 & 1.526 & 0.130 & Tidak Signifikan \\
\hline X4 & 0.214 & 0.236 & 2.251 & 0.027 & Signifikan \\
\hline X5 & 0.055 & 0.095 & 1.110 & 0.270 & Tidak Signifikan \\
\hline
\end{tabular}

Sumber : Data primer diolah, 2018

Berdasarkan Tabel diatas perhitungan regresi linear berganda dengan menggunakan program SPSS versi 21 didapat hasil sebagai berikut:

$$
Y=1.200+0.211 X_{1}+0.113 X_{2}+0.120 X_{3}+0.214 X_{4}+0.055 X_{5}
$$

- Pengujian hipotesis parsial $(t)$

a. Berdasarkan hasil analisis menunjukkan bahwa terdapat nilai thitung sebesar 3.370>0.299 dan signifikansi sebesar 0,001 $(0,001<0,05)$. Nilai tersebut dapat membuktikan bahwa hipotesis diterima, artinya "Tangible berpengaruh signifikan terhadap kepuasan mahasiswa".

b. Berdasarkan hasil analisis menunjukkan bahwa terdapat nilai thitung sebesar $1.400>0.166$ dan nilai signifikansi sebesar 0,165 $(0,165>$ $0,05)$. Nilai tersebut dapat membuktikan bahwa hipotesis ditolak, 
artinya"Reliability tidak berpengaruh terhadap kepuasan mahasiswa".

c. Berdasarkan hasil analisis menunjukkan bahwa terdapat nilai thitung sebesar 1.526>0.145 dan nilai signifikansi sebesar $0,130 \quad(0,130>$ $0,05)$. Nilai tersebut dapat membuktikan bahwa hipotesis ditolak, artinya "Responsiveness tidak berpengaruh terhadap kepuasan mahasiswa".

d. Berdasarkan hasil analisis menunjukkan bahwa terdapat nilai thitung sebesar $2.251>0,236$ dan nilai signifikansi sebesar 0,027 $(0,027<$ $0,05)$ ). Nilai tersebut dapat membuktikan bahwa hipotesis diterima, artinya "Assurance berpengaruh signifikan terhadap kepuasan mahasiswa".

e. Berdasarkan hasil analisis menunjukkan bahwa terdapat nilai thitung sebesar 1.110>0.095 dan nilai signifikansi sebesar $0,270(0,270>$ $0,05)$ ). Nilai tersebut dapat membuktikan bahwa hipotesis diterima, artinya "Empathy berpengaruh terhadap kepuasan mahasiswa".

\section{- Koefisien determinasi}

Tabel 4.8

Koefesien Determinasi

\begin{tabular}{|l|r|r|r|r|}
\hline Model & R & R Square & $\begin{array}{c}\text { Adjusted R } \\
\text { Square }\end{array}$ & $\begin{array}{c}\text { Std. Error of } \\
\text { the Estimate }\end{array}$ \\
\hline 1 & $.753^{\mathrm{a}}$ & .567 & .542 & 1.902 \\
\hline
\end{tabular}

Berdasarkan analisis regersi linear berganda menunjukkan besarnya koefisien determinasi $\left(r^{2}\right.$ square $)=0,542$, artinya variabel bebas secara bersama-sama mempengaruhi variabel tidak bebas sebesar $54.2 \%$ sisanya sebesar $45.8 \%$ dipengaruhi oleh variabel lain yang tidak dimasukkan dalam model penelitian ini.

\section{HASIL DISKUSI}

\section{a. Pengaruh tangible terhadap kepuasan mahasiswa}

Tangible (Bukti fisik) berpengaruh signifikan terhadap kepuasan mahasiswa. Dengan demikian, semakin tinggi kehandalan maka semakin tinggi tingkat kepuasan mahasiswa. Bukti fisik merupakan dari Fakultas Ekonomi Uniku, seperti penataan interior dan eksterior yang baik, kerapian dan kebersihan ruangan perkuliahan. Bukti fisik ini bisa mempengaruhi kenyamanan dan kelancaran dalam memberikan pelayanan kepada setiap mahasiswa. Hal ini dapat dilihat dari sebagian besar mahasiswa yang menyatakan persetujuannya, artinya kondisi fisik pada Fakultas Ekonomi Uniku sudah sesuai dengan keinginan mahasiswa. Semakin mendukung kondisi fisik di Fakultas Ekonomi Uniku, maka akan mempengaruhi kepuasan mahasiswa.

b. Pengaruh reliability terhadap kepuasan mahasiswa 
Reliability tidak berpengaruh signifikan terhadap kepuasan mahasiswa. Keandalan merupakan kemampuan memberikan pelayanan yang dijanjikan dengan segera, akurat dan memuaskan oleh Fakultas Ekonomi Uniku, seperti ketepatan waktu bila berjanji, jujur dalam pelayanan dan berusaha menghindari kesalahan. Hal ini berarti kampus memberikan jasanya secara tepat semenjak saat pertama. Keandalan di sini merupakan sejauh mana para tenaga kependidikan dan dosen bisa secara cepat tanggap dalam memahami dan mengatasi permasalahan yang dihadapi oleh para mahasiswa. Semakin handal hasil yang diperlihatkan oleh tenaga kependidikan dan dosen maka permasalahan yang dihadapi oleh para mahasiswa akan cepat terselesaikan.

\section{c. Pengaruh responsiveness terhadap kepuasan mahasiswa}

Daya tanggap merupakan keinginan para tenaga kependidikan dan dosen Fakultas Ekonomi Uniku untuk membantu para mahasiswa dan memberikan pelayanan dengan tanggap, seperti siap membantu mahasiswa, kecepatan dalam pelayanan dan komunikasi yang lancar. Daya tanggap di sini dapat berarti respon atau kesigapan tenaga kependidikan dalam membantu mahasiswa dan memberikan pelayanan yang cepat. Semakin tinggi daya tanggap yang diperlihatkan oleh tenaga kependidikan maka permasalahan yang dihadapi oleh para mahasiswa akan cepat terselesaikan. Semakin tinggi tingkat daya tanggap tenaga kependidikan dan dosen Fakultas Ekonomi Uniku, maka akan mempengaruhi kepuasan mahasiswa.

Berdasarkan hasil penelitian yang dilakukan menunjukkan bahwa pelaksanaan dimensi kualitas jasa responsiveness oleh Fakultas Ekonomi Uniku belum cukup baik. Pelayanan yang responssivess atau daya tanggap, juga sangat dipengaruhi sikap tenaga kependidikan. Apabila sikap tenaga kependidikan yang mampu tanggap akan apa yang menjadi kebutuhan mahasiswa sehingga mahasiswa akan merasa puas akan jasa Fakultas Ekonomi Uniku yang diterima.

\section{d. Pengaruh assurance terhadap kepuasan mahasiswa}

Assurance (Jaminan) berpengaruh signifikan terhadap kepuasan mahasiswa. Jaminan merupakan pengetahuan, kemampuan, kesopanan, dan sifat dapat dipercaya yang dimiliki para tenaga kependidikan Fakultas Ekonomi Uniku untuk membantu para mahasiswa, seperti pelayanan sopan, trampil dalam melaksanakan tugas dan pengetahuan memadai. Semakin tinggi jaminan yang diperlihatkan oleh tenaga kependidikan Fakultas Ekonomi Uniku, maka akan mempengaruhi kepuasan mahasiswa.

Salah satu dari dimensi kualitas jasa yang menentukan kepuasan mahasiswa adalah assurance, yaitu dimensi yang kualitas jasa yang berhubungan dengan kemampuan Fakultas Ekonomi Uniku dalam menanamkan rasa percaya dan keyakinan kepada mahasiswa. Hal ini berarti jika pelaksanaan pelayanan melalui dimensi kualitas 
jasa yang ia terima. Berarti assurance merupakan salah satu faktor yang memberikan sumbangan terhadap kepuasan mahasiswa.

e. Pengaruh empathy terhadap kepuasan mahasiswa

Empati merupakan kemudahan dalam melakukan hubungan, komunikasi yang baik, perhatian pribadi, dan memahami kebutuhan para mahasiswa oleh Fakultas Ekonomi Uniku, seperti perhatian kepada pelanggan, tanggung jawab keamanan dan kenyamanan serta mengutamakan kepentingan mahasiswa. Semakin tinggi empathy yang diperlihatkan oleh tenaga kependidikan dan dosen Fakultas Ekonomi Uniku, maka akan mempengaruhi kepuasan mahasiswa. Berdasarkan hasil penelitian yang dilakukan menunjukkan bahwa pelaksanaan dimensi kualitas jasa empathy oleh Fakultas Ekonomi Uniku terlihat belum optimal. Pemberian pelayanan empathy belumsepenuhnya memperhatikan apa yang menjadi kebutuhan mahasiswa dan akan memberikan kepuasan kepada mahasiswa.

Berdasarkan hasil penelitian yang dilakukan menunjukkan bahwa pelaksanaan dimensi kualitas jasa empathy oleh Fakultas Ekonomi Uniku terlihat belum optimal. Pemberian pelayanan empathy belum sepenuhnya memperhatikan apa yang menjadi kebutuhan mahasiswa dan akan memberikan kepuasan kepada mahasiswa.

\section{KESIMPULAN}

Berdasarkan analisis dan pembahasan tersebut di atas, maka kesimpulannya adalah sebagai berikut:

1. Tangible berpengaruh signifikan terhadap kepuasan mahasiswa.

2. Reliability tidak berpengaruh terhadap kepuasan mahasiswa .

3. Responsiveness tidak berpengaruh terhadap kepuasan mahasiswa.

4. Assurance berpengaruh signifikan terhadap kepuasan mahasiswa.

5. Emphaty tidak berpengaruh terhadap kepuasan mahasiswa. 


\section{IMPLIKASI}

1. Tangible (X1) terdapat pengaruh signifikan terhadap kepuasan mahasiswa ini menjadikan pihak pengelola Fakultas Ekonomi Uniku agar lebih memperhatikan konsistensi penataan interior dan eksterior yang lebih baik lagi, kerapian dan kebersihan ruangan harus selalu dalam kondisi bersih serta teknologi sebagai sarana penunjang dalam proses belajar perlu lebih diperhatikan dan ditingkatkan lagi.Pemberian pelayanan sebaiknya memperhatikan apa yang menjadi kebutuhan dari mahasiswa yang menunjang dalam proses belajar mengajar

2. Reliability (X2) tidak ada pengaruh terhadap kepuasan mahasiswa ini menunjukkan bahwa tenaga kependidikan masih kurang cepat dalam memberikan pelayanan yang maksimal kepada mahasiswa,oleh karena itu perlu adanya pelatihan bagi para tenaga kependidikan dalam memberikan pelayanan yang kepada mahasiswa

3. Responssive (X3) tidak ada pengaruh terhadap kepuasan mahasiswa ini menunjukkan bahwa tenaga kependidikan masih kurang tanggap/peka terhadap merespon akan kebutuhan mahasiswa sehingga sehingga pada masa yang akan datang pihak fakultas ekonomi uniku agar dapat lebih tanggap lagi dalam memberikan pelayanan sehingga mahasiswa dapat merasa puas.

4. Assurance (X4) terdapat pengaruh terhadap kepuasan mahasiswa ini menunjukkan bahwa dengan adanya pemberian bea siswa kepada mahasiswa yang berprestasi dan mahasiswa kurang mampu akan memberikan kepuasan kepada mahasiswa, pemberian jaminan ini tidak terbatas pada pemberian beasiswa tetapi juga adanya jaminan2 lainnya seperti adanya jaminan kesehatan, jaminan mendapatkan kesempatan pekerjaan, jaminan keamanan selama mengikuti proses belajar di kampus sehingga dengan adanya beberapa jaminan tersebut mahasiswa akan merasa puas.

5. Emphaty (X5) tidak ada pengaruh terhadap kepuasan mahasiswa,oleh karena itu pihak Fakultas Ekonomi Uniku harus memberikan perhatian lebih khusus kepada mahasiswa terutama bagi mahsiswa yang mempunyai masalah sehingga perlu adanya bimbingan konseling bagi mahasiswa karena selama ini di Fakultas Ekonomi belum ada Bimbingan Konseling bagi mahasiswa.

6. Perlunya adanya pengembangan variabel-variabel dependen dan independen pada masa yang akan datang untuk menunjang dan menghasilkan hasil penelitian yang maksimal

\section{REFERENSI}

Abdul Manap, 2016 Revolusi Manajemen Pemasaran, Penerbit Mitra Wacana Media Jakarta, Edisi Pertama 
Arthur Middleton Hughes. 2003. The Customer Loyalty Solution, What Works (And what doesn't) in Customer Loyalty Program. McGrawHill New York Chicago San Francisco Lisbon London

Augusty Ferdinand 2014 Metode Penelitian Manajemen Pendekatan Penelitian Skripsi Tesis dan Disertasi Ilmu Manajemen, Penerbit : Badan penerbit Universitas Diponogoro, Edisi Kelima

Buchari Alma, 2013 Manajemen Pemasaran dan Pemasaran Jasa, Penerbit Alfabeta Bandung, Edisi Revisi

Derek R. Allen. 2004. Customer Satisfaction Research Management. ASQ Quality Press Milwaukee, Wisconsin

Desan Henriawan, 2015.Pengaruh Kualitas Pelayanan dan Kepuasan Pelanggan terhadap Loyalitas Pelanggan.Jurnal.Universitas Sebelas April.Jakarta

Etta Mamang Sangadji dan Sopiah, 2013 Perilaku Konsumen, Pendekatan Praktis Disertai Himpunan Jurnal Penelitian, Penerbit Andi Yogyakarta, Edisi 1

Fandy Tjiptono, Gregorius Chandra, 2011 Service, Quality \& Satisfaction, Penerbit Andy Yogyakarta, Edisi 3

Husaini Usman, 2014. Manajemen Teori, Praktik, dan Riset Pendidikan Penerbit Bumi Aksara Edisi 4

Imam Ghozali 2016, Aplikasi Analisis Multivariete Dengan Program IBM SPSS 23 Badan Penerbit Universitas Diponogoro, Edisi 8

Idham Febry,B,2013.Pengaruh Dimensi Kualitas Layanan dengan implikasi loyalitas pada bank PT. BTPN.Jurnal of Bussiness and Banking.Volume 3 No.1 (May). Jakarta

Kotler, Philip dan A.B Susanto. 2012. Manajemen Pemasaran Jasa Di Indonesia, Analisis Perencanaan, Implementasi dan pengendalian (Edisi 12). Jakarta: Salemba Empat.

Dilndonesia (Buku 28. Jakarta: Salemba Empat.

Kotler, Philip. 2012. Manajemen Pemasaran (Edisi Milenium). Jakarta: PT Prenhalindo.

Kusumasitta, 2014. Relevansi Dimensi Kualitas Pelayanan dan kepuasan Pelanggan bagi pengunjung Museum Di Taman Mini Indonesia Indah.Jurnal Volume 1, No.1.Universitas Trisakti.Jakarta

Moh. Nazir, 2011 Metode Penelitian, Penerbit Ghalia Indonesia, Bogor Cetakan 7

Riduwan, 2010 Metode dan Teknik Menyusun Tesis, Penerbit Alfabeta Bandung

Riduwan, 2012 Metode \& Teknik Menyusun Proposal Penelitian (untuk Mahasiswa S-1, S-2, dan S-3), Penerbit Alfabeta Bandung

Reina, 2015. Faktor-faktor yang mempengaruhi kepuasan mahasiswa pada Universitas Bina Nusantara.Jurnal Fakultas IImu Komputer.BINUS University. Jakarta

Sugiyono, 2014 Metode Penelitian Manajemen Pendekatan : 1. Kuantitatif, 2. Kualitatif, 3. Kombinasi (Mixed methods), 4. 
Penelitian Tindakan (Action Research), 5. Penelitian Evaluasi, Penerbit Alfabeta, Bandung Cetakan ke3

Suhaji, 2015. Faktor-faktor yang mempengaruhi kepuasan pelanggan pada UD Pandan Wangi Semarang.Jurnal STIE Widya Manggala

Darwansyah. (2017). Pengaruh Kualitas Pelayanan Terhadap Kepuasan Konsumen Dalam Menggunakan Jasa Kamar Hotel Pada Hotel Grand. Ejournal Ilmu Administrasi Bisnis, 5(1), 1-12.

Natalia Ribka Lumempow, S. M., \& Rotinsulu, J. J. (2015). Analisis Faktor-Faktor Kualitas Pelayanan Terhadap Kepuasan The Analysis Of Factors Of The Quality Of Customer Satisfaction On Pt . Bank Mandiri, 3(3), 1275-1286.

Yonas Boky, 2016. Analisis Tingkat Kepuasan Mahasiswa Terhadap Pelayanan Akademik Sekolah Tinggi Theologia Jaffray.Jurnal Volume 14,No.2.Makassar 